Jurnal Tarbawi| Volume 2|No 2| ISSN 2527-4082| 100

\title{
MENSINERGIKAN TRI PUSAT PENDIDIKAN DALAM PEMBENTUKAN AKHLAK AL-KARIMAH (KARAKTER) PESERTA DIDIK
}

\author{
Wahdaniyah $^{1}$ \\ ${ }^{* 1}$ Pendidikan Agama Islam Fakultas Agama Islam| Unismuh Makassar
}

\begin{abstract}
ABSTRAK
Studi ini bertujuan untuk mendeskripsikan sinergi tri pusat pendidikan dalam pembinaan akhlak al-karimah peserta didik. Generasi muda yang berakhlak mulia adalah penerus bangsa yang menjadi tumpuan dan harapan semua pihak untuk menata masa depan yang lebih baik dan sangat diharapkan untuk menggantikan estafet kepemimpinan bangsanya. Harapan tersebut menjadi suatu keprihatinan mendalam, ketika menyaksikan situasi akhirakhir ini para generasi muda terjerumus dalam berbagai penyimpangan. Derasnya arus modernisasi lewat kemajuan ilmu pengetahuan dan teknologi serta jaringan-jaringan yang canggih telah memudahkan para generasi muda melakukan penyimpangan. Banyaknya informasi yang menyesatkan, hiburan yang lebih mempertontonkan kekerasan dan pornografi dengan pola sekuler yang senantiasa dihadirkan dapat menghancurkan akhlak dan kepribadian generasi muda. Atas dasar inilah seharusnya semua pihak perlu memberikan perhatian secara maksimal terhadap bidang pendidikan akhlak.
\end{abstract}

\section{Kata Kunci: Tri Pusat Pendidikan, Akhlak dan Peserta Didik}

\begin{abstract}
This study aims to describe the synergy of tri center education in the development of good moral (Akhlak Al-Karimah). The young generation of good moral is the next generation that become basic and goal all elements to organize a better future and expected to replace the national leadership relay. The expectation becomes a deep concern, when looking the currently of situation that the next generation fall into various of deviations. The rapid flow of modernization through advancement of science, technology, and sophiscated networks has made the young generation are easier to make deviation. A lot of misleading information, entertainment that show more violence and pornography with secular patterns that always presented can destroy moral and personality of young generation. On this basis all elements should need to give most attention toward moral of education.
\end{abstract}

Keywords: Tri Education Center, Morals and Learners 


\section{PENDAHULUAN}

Pembinaan akhlak merupakan tumpuan perhatian dalam Islam. Oleh karena itu, risalah utama Rasulullah Muhammad saw. Diutus Allah swt. adalah untuk menyempurnakan akhlak mulia, sebagaimana hadis yang berbunyi:

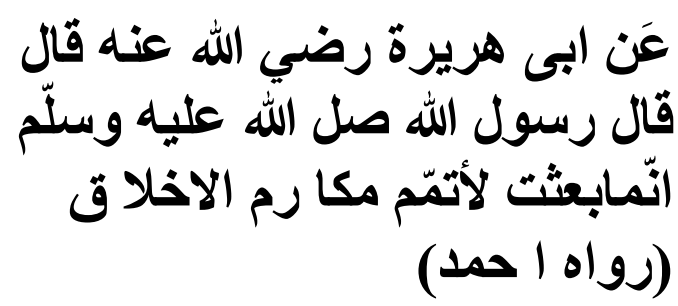

Artinya:

Dari Abi Hurairah ra. Berkata, Rasulullah saw. bersabda: Aku diutus untuk menyempurnakan akhlak mulia (H.R. Ahmad). (Ahmad bin Muhammad Ibnu Hanbal, 1996 :223).

Pilar utama untuk tumbuh dan berkembangnya peradaban suatu bangsa adalah dengan akhlak mulia. Kemampuan suatu bangsa untuk bertahan ditentukan oleh sejauhmana rakyat dan bangsa tersebut menjunjung tinggi nilai-nilai akhlak. Jika akhlak mulia terabaikan, tentu akan lahir kekacauan dan kehancuran dalam masyarakat.

Akhlak merupakan alat kontrol psikis dan sosial bagi individu dan masyarakat. Tanpa akhlak manusia berada dengan kumpulan binatang yang tidak memiliki tata nilai dalam kehidupannya Upaya menegakkan akhlak mulia bangsa merupakan suatu keharusan mutlak. Akhlak yang mulia akan menjadi pilar utama untuk tumbuh dan berkembangnya peradaban suatu bangsa. Semakin baik akhlak dan moral suatu bangsa, semakin baik pula bangsa yang bersangkutan atau sebaliknya. Negara manapun akan rusak dan mengalami kemunduran kalau tidak punya generasi yang berakhlak mulia. (Said Agil Husin Al Munawar, 2005 : 25).

Generasi muda yang berakhlak mulia adalah penerus bangsa yang menjadi tumpuan dan harapan semua pihak untuk menata masa depan yang lebih baik dan sangat diharapkan untuk menggantikan estafet kepemimpinan bangsanya. Harapan tersebut menjadi suatu keprihatinan mendalam, ketika menyaksikan situasi akhir-akhir ini para generasi muda terjerumus dalam berbagai penyimpangan. Derasnya arus modernisasi lewat kemajuan ilmu 
pengetahuan dan teknologi serta kualitas sistem pembelajaran yang jaringan-jaringan yang canggih telah dikembangkan harus mampu secara memudahkan para generasi muda cepat memperbaiki kelemahan yang ada. melakukan penyimpangan. Banyaknya informasi yang menyesatkan, hiburan yang lebih mempertontonkan kekerasan dan pornografi dengan pola sekuler yang senantiasa dihadirkan dapat menghancurkan akhlak dan kepribadian generasi muda.

Pendidikan menjadi sarana bagi pembentukan karakter, intelektual dan bakat peserta didik. Atas pertimbangan inilah selayaknya semua pihak perlu memberikan perhatian secara maksimal terhadap bidang pendidikan akhlak. Perhatian tersebut antara lain direalisasikan melalui kerja keras secara kontinyu dalam memperbaharuai dan meningkatkan kuwalitas pendidikan dari waktu-waktu, untuk menjawab kebutuhan, tuntunan dan permasalahan yang tengah dihadapi masyarakat sebagai konsekwensi dari tuntunan zaman. ( Zubaidi, 2009).

Tuntunan masa depan bukan hanya bersifat kompetitif, tapi juga sangat terkait dengan berbagai kemajuan teknologi dan informasi, oleh karena itu Pembaharuan mengiringi perputaran zaman yang tak henti-hentinya berputar sesuai dengan kurun waktu yang telah ditentukan. Oleh karena itu, lembaga pendidikan dituntut mampu mengantisipasi perkembangan tersebut dengan terus menerus mengupayakan suatu program yang sesuai dengan perkembangan anak, perkembangan zaman, situasi, kondisi, dan kebutuhan peserta didik. (Udin Saefudin, 2008 : 180).

Tanggung jawab dalam pendidikan Islam merupakan permasalahan yang penting dikaji dalam upaya mencapai tujuan pendidikan yang telah ditetapkan. Peserta didik mengalami pendidikannya dalam tiga lingkungan, yaitu lingkungan keluarga dan yang bertanggung jawab adalah orang tua, di lingkungan sekolah adalah guru dan lingkungan masyarakat adalah seluruh masyarakat, khususnya para pemimpin/tokoh masyarakat. Oleh karena itu tidak benar anggapan yang menyatakan bahwa segala tanggung 
jawab itu hanya ada di pundak salah satu dari dari ketiga pihak tersebut. Karena sesungguhnya ketiga unsur tersebut yakni, orang tua, guru, dan masyarakat harus secara bersama-sama ikut memikul tanggung jawab dalam mendidik.

Berdasarkan latar belakang di atas, pokok masalah dalam penelitian ini adalah bagaimana tanggung jawab lembaga pendidikan dalam pembentukan akhlak alkarimah peserta didik? Pokok masalah tersebut diuraikan ke dalam beberapa sub masalah dengan rumusan sebagai berikut:

1. Bagaimana tanggung jawab orang tua dalam pendidikan akhlak peserta didik di keluarga?

2. Bagaimana tanggung jawab guru dalam pendidikan akhlak peserta didik di sekolah?

3. Bagaimana tanggung jawab pemerintah dan tokoh masyarakat dalam pembentukan akhlak peserta didik di lingkungan masyarakat?

\section{METODE PENELITIAN}

Jenis penelitian ini adalah penelitian deskriptif kualitatif. Penelitian deskriptif adalah penelitian yang bertujuan untuk menyelidiki dan menggambarkan keadaan, kondisi, situasi, peristiwa dan kegiatan. Secara aplikatif pelaksanaan metode penelitian deskriptif kualitatif tidak terbatas hanya sekedar pengumpulan dan penyusunan data, tetapi meliputi analisis dan interpretasi tentang arti data tersebut. Dalam penelitian deskriptif ini penulis berusaha mencatat, menganalisa, dan mngintrepretasikan kondisi yang ada. Adapun orientasi tulisan ini adalah mengkaji secara mendalam tentang tanggung jawab pendidik dalam pembentukan Akhlak Al-karimah (karakter) peserta didik.

\section{HASIL DAN PEMBAHASAN}

Tanggung Jawab Orang Tua dalam Pendidikan Akhlak di Keluarga

Keluarga adalah unit sosial terkecil yang memberikan pondasi primer bagi perkembangan peserta didik. Keluarga merupakan tempat pertama peserta didik menerima pendidikan. Orang tua adalah penanggung jawab yang utama dan pertama dalam pendidikan di keluarga. Sebagai peletak 
pertama pendidikan, orang tua memegang peranan yang sangat penting bagi pembentukan watak dan kepribadian anak. Dalam arti bahwa watak dan kepribadian anak tergantung pada pendidikan awal orang tua terhadap anaknya, Rasullah saw. bersabda yang artinya:

Setiap anak dilahirkan atas dasar fitrah, kedua orang tuanyalah yang menjadikan ia Yahudi, Nasrani, dan Majusi. (H.R.Bukhari). (Abu Abdillah Muhammad Ibn Ismaail al Bukhary al July, Shahih Bukhariy, 1992:42).

Anak adalah amanah yang melahirkan rasa tanggung jawab yang sungguh-sungguh pada diri setiap orang tua. Amanah itu meliputi kewajiban menjaga kelangsungan kehidupan anak dengan memberikan makanan, minuman, tempat perlindungan, menjaga akidahnya sehingga tetap berada dalam agama dan keyakinan yang benar dan memberikan bekal pendidikan (Siti Musdah Mulia, 2011:97).
Lebih jauh lagi sejak penentuan pemilihan jodoh yang bakal menjadi calon ibu dan ayah. Hal ini terkait dengan firman Allah swt. (Q.S. al-A'raf 17: 58)
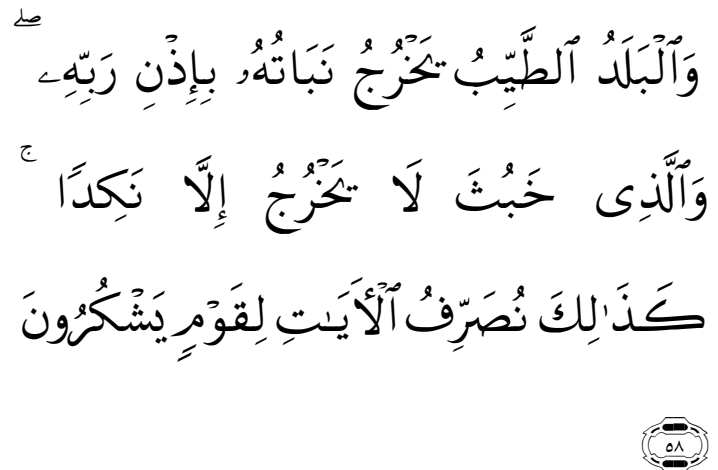

Terjemahnya:

Dan tanah yang baik, tanamantanamannya tumbuh subur dengan seizin Allah; dan tanah yang tidak subur, tanamantanamannya hanya tumbuh merana. Demikianlah Kami mengulangi tanda-tanda kebesaran (Kami) bagi orangorang yang bersyukur.

Ayat tersebut mengisyaratkan bahwa Sebagaimana biji tanaman yang hendak ditanam, tentunya membutuhkan lahan yang subur dan bersih dari penyakit atau tumbuhan penganggu. Demikian juga anak-anak yang hendak dilahirkan, jika motivasi pembentukan lembaga keluarga didasarkan atas niat 
yang suci begitu juga dengan pergaulan suami istri, maka hal itu identik dengan menempatkan janin dalam lahan yang suci dari berbagai gangguan. Sebaliknya jika motivasi perkawinan dan hubungan suami istri didasarkan pada pretensipretensi materialistik dan kesyirikan, hal ini sama halnya menempatkan janin anak-anak pada lahan yang penuh penyakit dan gangguan (Suharsono, 2000:109).

Pembentukan akhlak yang baik dilaksanakan pada awal kehidupan manusia yakni pada saat berada dalam kandungan. Janin yang berada dalam kandungan ibunya mendapat pengalaman lewat syaraf-syaraf di dalam rahim ibunya. Dalam perspektif Islam, rahim ibu tidak hanya memiliki makna biologis bagi janin, tetapi lebih jauh dari itu, sebagai transmisi pendidikan yang akan berpengaruh pada pertumbuhan spiritual, intelektual dan bahkan keteguhan diri. Rahim ibu adalah sebagai lahan di mana bibit sebuah tanaman akan tumbuh berkembang. Karena perannnya sebagai lahan, sudah barang tentu akan memberikan pengaruh yang sangat kuat terhadap bibit yang ditanam padanya.

Kesalehan orang tua secara langsung merupakan input pendidikan bagi anak ketika masih menjadi janin dalam rahim ibunya. Dan ketika lahir, agama Islam menganjurkan yang terbaik bagi pertumbuhan dan perkembangan anak adalah dengan air susu ibu. Air susu ibu memiliki dampak secara langsung dan mendalam terhadap kesehatah jasmani dan rohani anak, sebagaiman dalam (Q.S. al`Baqarah (2):233).

\section{Tanggung Jawab Guru dalam} Pendidikan Akhlak di Sekolah

Ajang pendidikan kedua setelah keluarga adalah di sekolah. Ketika seorang anak mulai masuk sekolah, itu artinya ia menghadapi masyarakat baru yang berbeda dengan masyarakat keluarganya. Di sekolah teerdapat individu-individu yang belum pernah bersamaya dalam kehidupan keluarganya. Proses mempersiapkan peserta didik untuk beradaptasi dengan sekolah termasuk salah satu proses sosial yang sangat susah dan sekaligus sangat 
penting, dan yang bertanggung jawab dan berperan dalam hal ini adalah guru.

Sekolah merupakan lembaga pendidikan yang diharapkan dapat mencetak manusia-manusia yang berguna. Dan yang terlibat langsung dalam semua proses pembelajaran tersebut adalah guru. Guru merupakan wali dari arang tua anak sebagai tempat anak mengadu, berdiskusi, meminta pendapat dari permasalahan yang dihadapi. Pada hakikatnya, guru dan peserta didik ibarat dua sisi mata uang, tidak dapat dipisahkan, tapi bisa dibedakan. Tanpa peserta didik, guru tidak akan dapat mengajar, dan begitu juga sebaliknya, keduanya saling membutuhkan. Keduanya saling memberi nilai dalam menjalani hidup di masyarakat. Kesatuan yang utuh inilah, jika tetap diprertahankan akan memberikan sebuah kekuatan yang dapat melahirkan sumber daya manusia yang berkualitas. Kecerdasan dan kecakapan peserta didik akan menjadi tiang keabadian dalam dunia pendidikan.

Guru adalah pendidik professional, karena secara implisit ia telah merelakan dirinya menerima dan memikul sebagian tanggung jawab pendidikan yang terpikul di pundak para oranng tua. Pada saat orang tua menyerahkan anaknya ke sekolah, berarti pelimpahan sebagian tanggung jawab pendidikan anaknya itu kepada guru.

Untuk mewujudkan pendidik yang profesional, kita dapat mengacu pada tuntunan Nabi muhammad saw., Beliau adalah teladan pendidik yang sukses, mampu mengubah peradaban yang terjerumus dalam jurang kebiadaban menuju peradaban baru yang penuh dengan kegemilangan.

Keberhasilan Nabi Muhammad saw., sebagai pendidik didahului oleh bekal kepribadian yang berkwalitas, unggul, kepeduliannya terhadap masalah-masalah sosial serta semangat dan ketajamannya dalam membaca, menganalisa, meneliti dan mengeksperimentasi terhadap berbagai fenomena kehidupan. Beliau mampu mempertahankan dan mengembangkan kualitas iman, amal saleh, berjuang dan bekerja sama menegakkan kebenaran (Bukhari Umar, 2010:93). 
Di sekolah, figur guru tangan seorang guru. Guru yang merupakan pribadi kunci. Gurulah panutan utama bagi peserta didik. Sikap dan prilaku guru akan senantiasa dilihat, didengar, dan ditiru oleh peserta didik. Konsekwensi tanggung jawab guru sangat berat. Kehadirannya diharapkan menjadi teladan bagi peserta didik dan masyarakat sekitarnya, karena segala perilaku seorang guru mulai dari yang kecil sampai pada hal yang besar tidak luput dari sorotan di lingkungan sekolah maupun lingkungan masyarakat.

Guru yang memiliki kompetensi adalah sosok yang senantiasa merasa dirinya kekurangan dalam menimba ilmu pengetahuan dan pengalaman. Mereka tidak pernah memiliki perasaan gengsi apalagi meremehkan orang lain. Guru yang memiliki kompetensi akan memberikan kontribusi kearah kemajuan dan perubahan positif pada peserta didik.

Tanpa guru, hidup menjadi hampa, gelap, ibarat berjalan tanpa arah. Guru ibarat pelita dalam kegelapan. Guru sangat menentukan maju tidaknya sebuah bangsa. Ciri bangsa yang maju adalah adanya campur tangan dari memiliki kualitas dasar ilmu yang kuat akan menjadi tumpuan dalam mempercepat kelahiran generasigenerasi yang mandiri dan berakhlak. Hal ini sejalan dengan tuntutan zaman yang terus berubah. Oleh sebab itu, guru dituntut mampu mengikuti dan menyikapi tuntutan perubahan zaman tersebut. Apalagi dalam dunia globalisasi sekarang ini, booming informasi tak lagi sebuah hayalan tetapi benar-benar di hadapan kita dan bahkan bisa jadi kita sendiri menjadi objek dan sasaran dari informasi tersebut. Pengaruh buruk yang dibawah oleh berbagai media tersebut dapat merusak peserta didik jika mereka tidak mampu menyaring mana yang baik dan buruk.

Olehnya itu, sangat penting untuk membekali peserta didik dengan pendidikan akhlak al karimah agar mereka tidak mudah teombang ambing, terpuruk, terjebak, dalam situasi zaman yang menyesatkan. Para guru harus tampil sebagai figur teladan dan panutan bagi peserta didik. Guru sangat dituntut perannya dalam membentuk akal, membimbing, mengajarkan dan 
membekali peserta materi-materi pendidikan yang memuat nilai-nilai yang dapat membentuk akhlak mulia dan perilaku sosial secara ideal.

Tanggung Jawab Pemimpin dan Tokoh Masyarakat dalam Pendidikan Akhlak di lingkungan Masyarakat

Keadaaan masyarakat dan kondisi lingkungan dalam berbagai corak dan bentuknya akan berpengaruh, baik langsung maupun tidak langsung terhadap pendidkan peserta didik. Masyarakat merupakan faktor penting bagi kelangsungan pendidikan anak, karena sebagai makhluk sosial bagaimanapun anak tidak bisa dilepaskan dari lingkungan masyarakatnya.

Pengaruh sosial dan kultural memainkan peranan besar dalam menentukan tingkah laku pada anak didik. Kultur dan struktur masyarakat sangat nberimplikasi pada pendidikan anak, jika kultur dan struktur masyarakt baik, maka pendidikan anakpun akan condong kearah yang lebih positif. Namun sebaliknya bila situasi masyarakat buruk, maka juga berdampak pada anak yang lebih cenderung melakukan tindakan-tindakan negatif. Masyarakat besar pengaruhnya dalam memberi arah terhadap pendidikan anak, terutama para pemimpin masyarakat/tokoh masyarakat. Pemimpin yang berakhlak dan taat melaksanakan ajaran agama, tentu menghendaki agar setiap anak didik menjadi anggota masyarakat yang berakhlak dan taat menjalankan perintah agama. Dengan demikian di pundak mereka terpikul keikutsertaan membimbing pertumbuhan dan perkembangan anak. Ini berarti bahwa pemimpin dan tokoh masyarakat ikut bertanggung jawab terhadap penyelenggaraan pendididkan. Sebab tanggung jawab pendiddikan pada hakikatnya merupakan tanggung jawab moral dari setiap orang dewasa baik sebagai perorangan maupun kelompok sosial.

Sekalipun ajaran Islam menekankan tanggung jawab perseorangan dan pribadi bagi manusia, tetapi tidaklah mengabaikan tanggung jawab sosial yang menjadikan masyarakat sebagai masyarakat 
solidaritas, berpadu dan bekerjasama membiana dan mempertahankan kebaikan. Semua anggota masyarakat bertanggung jawab membina, memakmurkan, memperbaiki, mengajak kepada kebaikan dan mencegah kemunkaran. Hal ini terkait dengan salah satuFirman Allah swt. di dalam AlQur'an Surah Ali Imran (3):104

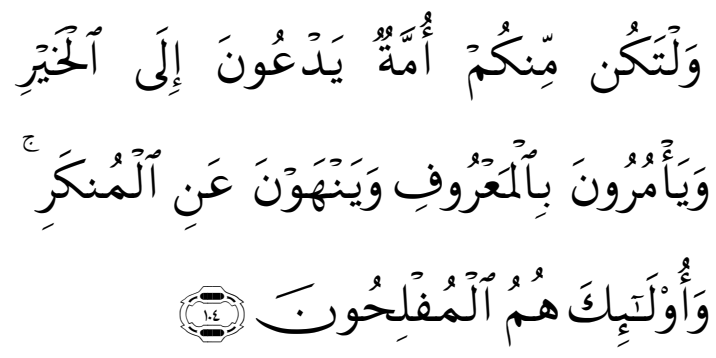

Terjemahnya:

Dan hendaklah ada di antara kamu segolongan umat yang menyeru kepada kebajikan, menyuruh kepada yang ma'ruf dan mencegah dari yang munkar[217]; merekalah orangorang yang beruntung.

Dengan demikian jelaslah bahwa tanggung jawab pendidikan tidak hanya bersifat personal, tetapi juga bersifat sosial. Tanggung jawab tersebut bukan hanya terhadap perbutannya dan perbaikan dirinya, tetapi juga bertanggung jawab terhadap perbuatan orang-orang yang berada di lingkungan sekitarnya.

Pembinaan dalam lingkungan masyarakat dapat dilakukan dengan berbagai kegiatan-kegiata yang berirentasi pada pembinaan akhlak. Melihat masyarakat sebagai suatu komponen yang dapat dikategorikan sebagai pendidik, masyarakat merupakan faktor yang integral dengan peserta didik, orang tua, dan guru, yang pada dasarnya memiliki peranan yang sama sesuai proses interaksi yang ada. Transformasi pendidikan yang ada dalam masyarakat seperti halnya pada orang tua, dan guru, yaitu adanya proses pematangan intelektual, keterampilan, dan terutama sekali sikap mental dan akhlak peserta didik.

\section{KESIMPULAN}

Tanggung jawab orang tua terhadap anak adalah suatu keniscayaan yang merupakan fitrah dan amanah yang telah dikodratkan Allah swt. kepada setiap orang tua. Olehnya itu kewajiban orang tua terhadap anak adalah menjaga kelangsungan kehidupan anak dengan 
memberikan makanan, minuman, tempat perlindungan, menjaga akidahnya sehingga tetap berada dalam agama dan keyakinan yang benar, dan memberikan bekal pendidikan. Guru adalah pendidik professional, karenanya secara implisit ia telah merelakan dirinya menerima dan memikul sebagian tanggung jawab pendidikan yang terpikul di pundak para oranng tua. Pada saat orang tua menyerahkan anaknya ke sekolah, berarti pelimpahan sebagian tanggung jawab pendidikan anaknya itu kepada guru. Guru adalah pendidik profesional dengan tugas utama mendidik, mengajar, membimbing, mengarahkan, melatih dan mengevaluasi peserta didik. Masyarakat besar pengaruhnya dalam memberi arah terhadap pendidikan anak, terutama para pemimpin masyarakat/tokoh masyarakat. Pemimpin yang berakhlak dan taat melaksanakan ajaran agama, tentu menghendaki agar setiap anak didik menjadi anggota masyarakat yang berakhlak dan taat menjalankan perintah Allah swt.

\section{DAFTAR PUSTAKA}

Asmaran, As. Pengantar Studi Akhlak. Cet. III; Jakarta: LSIK, 2002.

Arifin, Ilmu Pendidikan Islam, Tinjauan Teoritis dan Praktis Berdasarkan Pendekatan Interdisipliner, Cet. V. Jakarta: PT. Bumi Aksara; 2011.

Adhim, M. Fauzil. Cara-Cara Islami Mengembangkan Karakter Positif Pada Anak Anda, Cet.IV, Bandung: PT. Mizan Pustaka; 2008.

Al-Qarni, Aidh. Membina Rumah Tangga Bahagia, Cet.I. Bandung: Sinar Baru Algensindo, 2007

Alang, Sattu. Kesehartan Mental dan Terapi Islam, Cet. II. Makassar: Berkah Utami; 2005.

Ahmad Soeban. Beni. Ilmu Pendidikan Islam, Cet.I. Bandung: CV. Pustaka Setia, 2009.

Daradjat, Zakiah. Ilmu Pendidikan Islam, Cet.IX, Jakarta; Bumi Aksara, 2011.

Departemen Agama RI, Al-Qur'an dan Terjemahnya, Bandung: PT. Syaamil Cipta Mulia, 2005.

Khaeruddin, Ilmu Pendidikan Islam, Mendesain Insan yang Hakiki dan Mengintai Muslimah dalam Sejarahnya, Ed. I. Cet, I. Makassar: Berkah Utami; 2002. 
Mappanganro, Pemilikan Kompetensi Guru, Makassar: Alauddin Press; 2010.

Musdah Mulia, Siti. Membangun Surga di Bumi, Kiat-kiat Membina Keluarga Ideal dalam Islam (Jakarta: Ikapi, 2011

Mujib, Abdul. Ilmu Pendidikan Islam (Cet. II; Jakarta: Kencana, 2008

Rimang, Siti Suwadah, Meraih Predikat Gurudan Dosen yang Paripurna, Cet. I, Bandung : Alfabeta; 2011.

Sadulloh, Uyoh. Pedagogik (Ilmu Mendidik), Cet. I; Bandung, Alfabeta, 2010.

Suharsono, Mencerdaskan Anak, Cet. I. Jakarta; Intisari Press; 2000.

Umar, Bukhari, Ilmu Pendidikan Islam Cet. I, Jakarta, AMZAH, 2010.

Yunahar. Kuliah Akhlak. Cet. II; Yogyakarta: Pustaka pelajar, 2000. 